\title{
Modified cementless total coxofemoral prosthesis: development, implantation and clinical evaluation
}

\author{
[Prótese coxofemoral não cimentada: desenvolvimento, implantação \\ e avaliação clínica ] \\ S.A. Arias $^{1}$, J.R.T. Blanco ${ }^{2}$, J.V. Doretto ${ }^{3}$, G.L.T. Vieira ${ }^{4}$, H.P. Oliveira ${ }^{3}$, C.M.F. Rezende ${ }^{3 *}$ \\ ${ }^{1}$ Faculdade de Ciências Agropecuárias - Universidad de La Salle, Colômbia \\ ${ }^{2}$ Laboratório de Recobrimentos Térmicos LEMS - CETEC - Belo Horizonte, MG \\ ${ }^{3}$ Escola de Veterinária - Universidade Federal de Minas Gerais - Belo Horizonte, MG \\ ${ }^{4}$ Escola de Veterinária - Universidade de Purdue - Estados Unidos
}

\begin{abstract}
The aim of this study was to modify canine coxofemoral prostheses and the clinical evaluation of the implantation. Fifteen canine hips and femora of cadavers were used in order to study the surface points of modification in prostheses and develop a perforation guide. Femoral stems and acetabular components were perforated and coated with biphasic calcium phosphate layer. Twelve young adult male mongrel dogs were implanted with coxofemoral prostheses. Six were operated upon and implanted with cemented canine modular hip prostheses, establishing the control group. The remaining six were implanted with a novel design of cementless porous tricalcic phosphate-hydroxyapatite coated hip prostheses. Clinical and orthopedic performance, complications, and thigh muscular hypotrophy were assessed up to the $120^{\text {th }}$ post-operatory day. After 120 days, animals with cementless prostheses had similar clinical and orthopedic performance compared to the cemented group despite the increased pain thigh hypotrophy. Animals that underwent cementless hip prosthesis evidenced more pain, compared to animals with cemented hip prosthesis that required longer recuperation time. No luxations, two fractures and two isquiatic neurapraxies were identified in the course of the study. Using both the cemented and the bioactive coated cementless model were suitable to dogs, showing clinical satisfactory results. Osseointegration and biological fixation were observed in the animals with the modified cementless hip prosthesis.
\end{abstract}

Keywords: coxofemoral prosthesis, calcium phosphate, hydroxyapatite, dogs

\section{RESUMO}

O objetivo deste estudo foi modificar a prótese coxofemoral canina cimentada e avaliar os efeitos clínicos. Foram utilizadas 15 pelves e 15 fêmures de cadáveres de cães para modificações da haste, do componente acetabular e para a confecção de guia de perfuração. As hastes e componentes acetabulares foram perfurados e revestidos com uma camada de fosfato de cálcio bifásico. Doze cães machos, adultos jovens, sem raça definida, foram submetidos à cirurgia para o implante de prótese coxofemoral total. Seis cães receberam prótese modular cimentada, grupo controle, e seis, a prótese modificada não cimentada com revestimento de fosfato de cálcio bifásico. Foram avaliados a técnica de implantação, o desempenho clínico, o grau de hipotrofia muscular da coxa e as complicações durante 120 dias. Os animais com prótese não cimentada mostraram desempenho clínico similar aos animais com a prótese cimentada, porém mostraram maior hipotrofia muscular decorrente de dor e maior tempo de recuperação. Não foram observadas luxações. No entanto, duas fraturas e dois casos de neurapraxia isquiádica foram observados. A utilização de ambas as próteses coxofemorais, cimentada e não cimentada, com recobrimento bioativo são eficientes no cão, com resultados clínicos satisfatórios, mas a osteointegração e fixação biológica ocorreram na prótese com recobrimento de fosfato de cálcio bifásico, objetivo do tratamento que previne afrouxamento futuro.

Palavras-chave: prótese coxofemoral, fosfato de cálcio, hidroxiapatita, cães

Recebido em 11 de março de 2013

Aceito em 12 de setembro de 2013

*Autor para correspondência (corresponding author)

E-mail: cleuzaufmg@gmail.com 


\section{INTRODUCTION}

The development of bone-implant permanent fixation mechanisms is a constant challenge in total coxofemoral prosthesis implantation in the dog and human. Prosthesis fixation can be mechanical, biologic or by chemical ligation between the implant and bone. Mechanical fixation can be obtained with either the use of cement or screws (Hanson et al., 2006; Hummel et al., 2010). In biologic fixation the implant is coated with porous material leading to osseous growth inside the pore. In bioactive fixation, a bioactive material (hydroxyapatite, bioglass) is deposited onto prosthesis surface inducing osseous formation (Jasty et al., 1997; Fenollosa et al., 2000; Goyenvalle et al., 2006). Fixation with polymethylmethacrylate (PMMA) cement is the most used in canine hip prostheses and it offers immediate stability to the implant (Massat, 1995; Schulz, 2000).

Mechanical characteristics of PMMA confer to fixation of the capacity to absorb the stress and compression forces from the implant to the bone, as well as the low elasticity modulus of PMMA alleviating the high modulus from metallic implant. However, the efficacy of this fixation depends on cement penetration into the porosities of bone and cementing technique used. Despite the efficacy of PMMA fixation, interfacial fibrous membrane formation between cement and bone (Day et al., 1998; Sargeant and Goswami, 2006) can lead to micro-movement and aseptic loosening of the implant (Park et al., 1995; Sargeant and Goswami, 2006).

In order to improve implant stability and prevent fibrous interfacial tissue, several alternatives have been proposed precluding cement use. Structural modifications such as stem roughening surface, stem precoating with PMMA or bioceramics, and surgical technique alterations such as pulsating washing of femoral cavity, rigorous osseous hemostasia, drying of medullar cavity and insertion of the stem in a pressing way into the femur have been proposed (Schulz, 2000; Goyenvalle et al., 2006). In humans, bioactive coating of the implants (biologic fixation) is usually performed; requiring approximately twelve weeks for complete weight bearing of the limb (Park et al., 1995). The clinical evolution of dogs with bioactive cementless coated total hip joint replacement is relatively sparse in Veterinary Medicine.

The main goals of this study were to modify the cemented canine coxofemoral hip prosthesis, the surgical technique and to evaluate the new model of prosthesis, as well as its clinical effects in dogs.

\section{MATERIALS AND METHODS}

All procedures described below were approved by the Ethics Committee for Animal Experimentation (CETEA - Comitê de Ética em Experimentação Animal) of UFMG (protocol number 066/2004). Canine stainless steel ASTM F-138 coxofemoral stem prosthesis and ultrahigh weight polyethylene acetabular components (Implantes FICO, Argentina) were used as experimental material to modify and coat the implant surface. Six stems (three size 06 and three 07) were selected for femoral component modification and 21, 23, 25, 27 and $29 \mathrm{~mm}$ diameter cups for modification of acetabular component (Figure 1). Likewise, fifteen canine skeletal pelvises and femora from $20-30 \mathrm{~kg}$ weight dogs were macerated and used as models to perform stem and acetabular component structural modifications (Figure 2). The femoral stems were plotted on milimetric paper and perforation points were identified regarding information from anatomic points collected at the skeletal femora. Therefore, three $3 \mathrm{~mm}$-orifices spaced $1.5 \mathrm{~cm}$ apart were made on size 7 stems and two orifices on size 6 (Figure 1a). A template guide was designed to localize the stem orifices after femoral implantation, which was attached to the stem implantor, (Figure 1.c). On pelvic skeletal sections the inner width of pelvic facet was measured (Figure $2 b$ ) in order to determine specific points for prosthetic acetabular component perforation (Figure $1 \mathrm{~b}$ and $2 \mathrm{a}$ ). Using morphometric data, three points of perforation in the superior mid half of the acetabular component, which was inserted into the widest region of the pelvis (Figure $1 b$ and $2 b$ ), were found. 

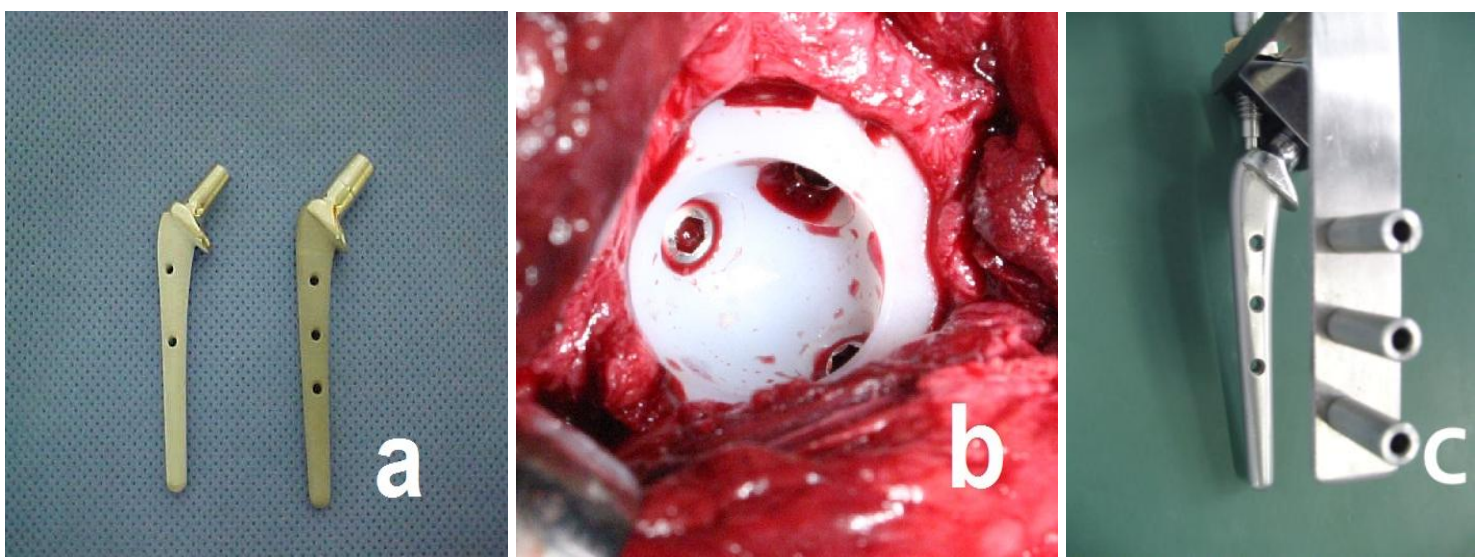

Figure 1. Modification of the stem (CETEC-UFMG). a) Stems from modified canine coxofemoral prostheses coated with biphasic calcium phosphate b) Transoperatory view of CETEC-UFMG acetabular component. Note the burying of the screw heads into the orifices made in the acetabular component wall. c) Stem guide.

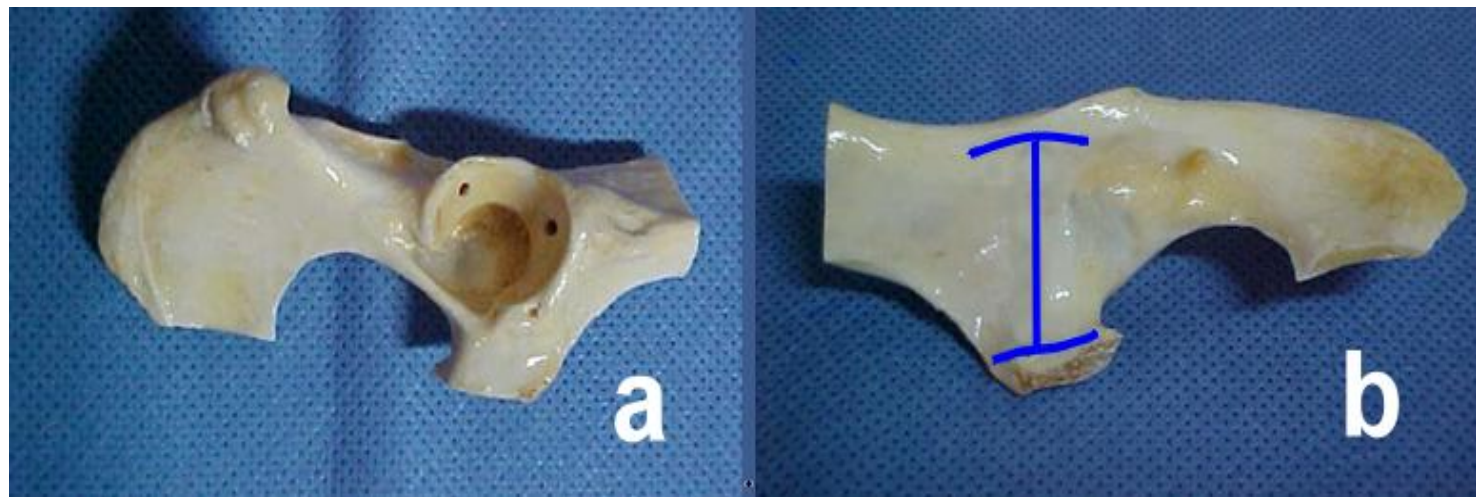

Figure 2. Canine hemipelvis, measurement of the internal width of pelvis conformed by Ilium and Ischia. a) hemi pelvis showing the cranio-dorsal and caudo-dorsal point of perforation; b) internal surface of the hemipelvis, the width of the surface located in a point cranio-dorsal in relation to the acetabulum is identified.

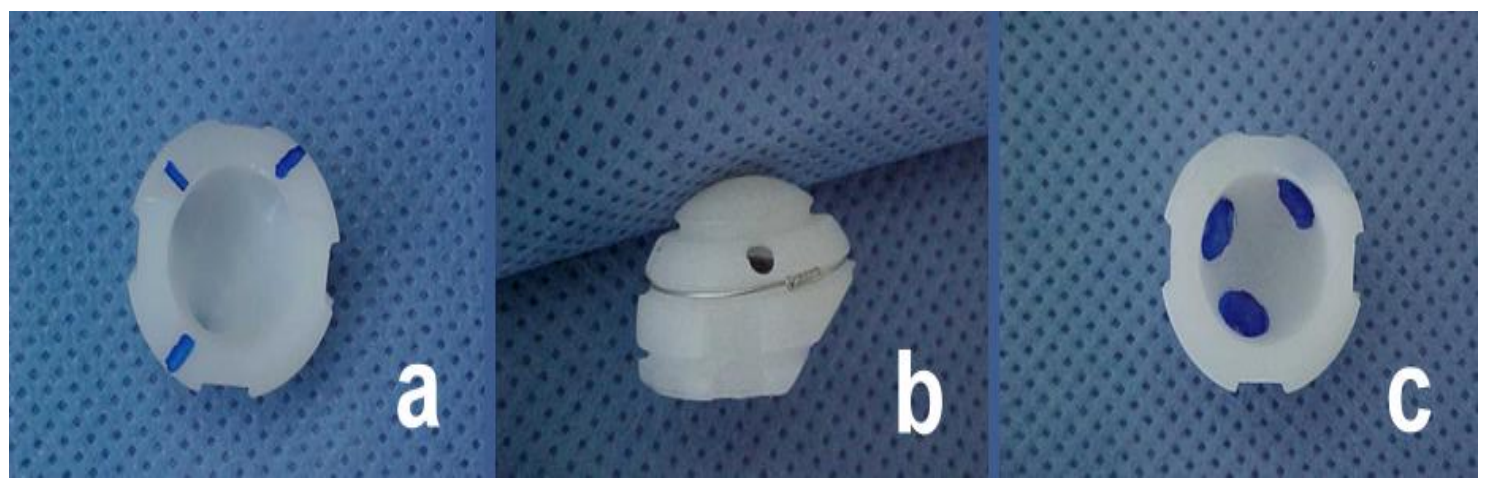

Figure 3. Canine modified acetabular component. a) transverse plane showing localization of the orifices at 7 o'clock (cranio-ventral), 10 o'clock (cranio-dorsal) and 1 o'clock (caudo-dorsal); b) sagittal plane, the orifices are localized at the midhalf portion of the acetabular component; c) orifice made from the fitting of the screw head in the cup wall. 
Using a clock face for familiarity, the orifices were made on transverse plane at 7 o'clock (cranio-ventral orifice), 10 o'clock (cranio-dorsal orifice) and 1 o'clock (caudo-dorsal orifice). (Figure 3a). On sagittal plane, the orifices were located in the superior midhalf of acetabular cup (Figure 3b). The shape of the orifices were fashioned in diagonal angle in relation to the pelvis wall for receiving a $2.7 \mathrm{~mm}$-cortical screw and burying the head of the screw into the acetabular cup wall (Figs. 1b and 3c).

After structural modification of the femoral and acetabular components, they were coated with a hydroxyapatite (65\%) and $\beta$-phosphate tricalcium (35\%) bioceramic (known as biphasic calcium phosphate) by means of plasma spray (Laboratório de Recobrimentos Térmicos, LEMS-CETEC, Belo Horizonte, Brasil), using 37- $150 \mu$ - granulometry powder (Silva, 2005). After training on canine cadavers, twelve healthy adult mongrel dogs of body mass between 18.8 $33.2 \mathrm{Kg}$ were selected. The dogs were vaccinated and observed in quarantine for fifteen days, during which orthopedic examination and radiographs were performed. All dogs were screened for either localized or systemic infections and only healthy animals were included in this study. Selected animals were divided into two groups of six dogs each: Group I, animals with stainless steel (ASTM-F-138) stem, UHWPE acetabular component and polymethylmethacrylate (PMMA)- cemented hip prosthesis. Group II, animals with modified biphasic calcium phosphate (BCP) coated cementless hip prosthesis.

All animals were starved for 12 hours previous to surgery and received preoperative intravenous (IV) $1 \mathrm{~g}$ cephalotin sodium (30 mg/kg, IV), acepromazine $(0.1 \mathrm{mg} / \mathrm{kg}, \quad \mathrm{IM}), \quad$ tramadol chlorhydrate (Acepran 1\% - Univet SA) $(2.0 \mathrm{mg} / \mathrm{kg}, \mathrm{IM})$ and anesthesia was induced with IV sodium thiopental (Thiopentax 2,5\% - Zeus life Science).

Anesthetic grade was maintained with inhalated Isoflurane (Fluotane - Baxter S.A.) at 2-3\% concentration. Trans-operative rate infusion of $10 \mathrm{ml} / \mathrm{kg} / \mathrm{hr}-0.9 \%$ sodium chloride was given during surgery and cephalexin (PO, 30 mg/kg, t.i.d) was given until negative intraoperative culture resulted. In dogs from Group I (cemented prosthesis), the surgical procedure was carried out according to Massat (1995) and Schulz (2000); in Group II (cementless BCP prosthesis) the surgical basic criteria were the same but inherent modifications due to the prosthesis alteration were taken into account. Head ostectomy was done at the level of lesser trochanter as reported by Schulz (2000) and acetabular cavity was reamed with a smaller reamer allowing implantation with a mild compression. Acetabular components were fixed with three $2.7 \mathrm{~mm}$-screws that were threaded until establishing stability and screw head fitting in component (Figure 1b). To fixate the screw to the acetabulum, the orifice was predrilled with a $2.0 \mathrm{~mm}$ Steinmann pin without using the tap.

Preparation of the femur for insertion of the prosthesis in Group II animals was performed with the aim of preserving cancellous bone and fitting the stem in compression. In one dog (Figure 4), the vastus laterallis muscle was partially elevated from cranial surface of femur in order to insert screws through the stem and bone. Only the most proximal orifice was threaded and a $2.7 \mathrm{~mm}$ screw was inserted with the aid of the guide. The remaining five dogs of the group did not receive screws for stem fixation. Intraoperative swabs were collected for bacterial culture and antibiogram.

Animals were held in cages for 24 hours and were treated with tramadol chlorhydrate (1.0mg/kg, t.i.d) and carprofen (2.0mg/kg, t.i.d.). In subsequent days, the animals were each housed in $4.5 \mathrm{~m}^{2}$ individual pens; movement was restricted to leash guided walking for 10 to 15 minutes per day.

Gait characteristics were evaluated for 120 days (Table 1.) and pain sensation along with Ortolani's test was performed in both limbs every two weeks until the $16^{\text {th }}$ postoperative week. Radiographs were taken immediately after surgery and the girth of the thigh was measured in orthostatic position and lateral recumbence by means of metric tape. The values were taken two centimeters distal to the greater trochanter, over the patellar recess and over the midpoint of the thigh. Each parameter was normalized dividing the value by corporal mass. 


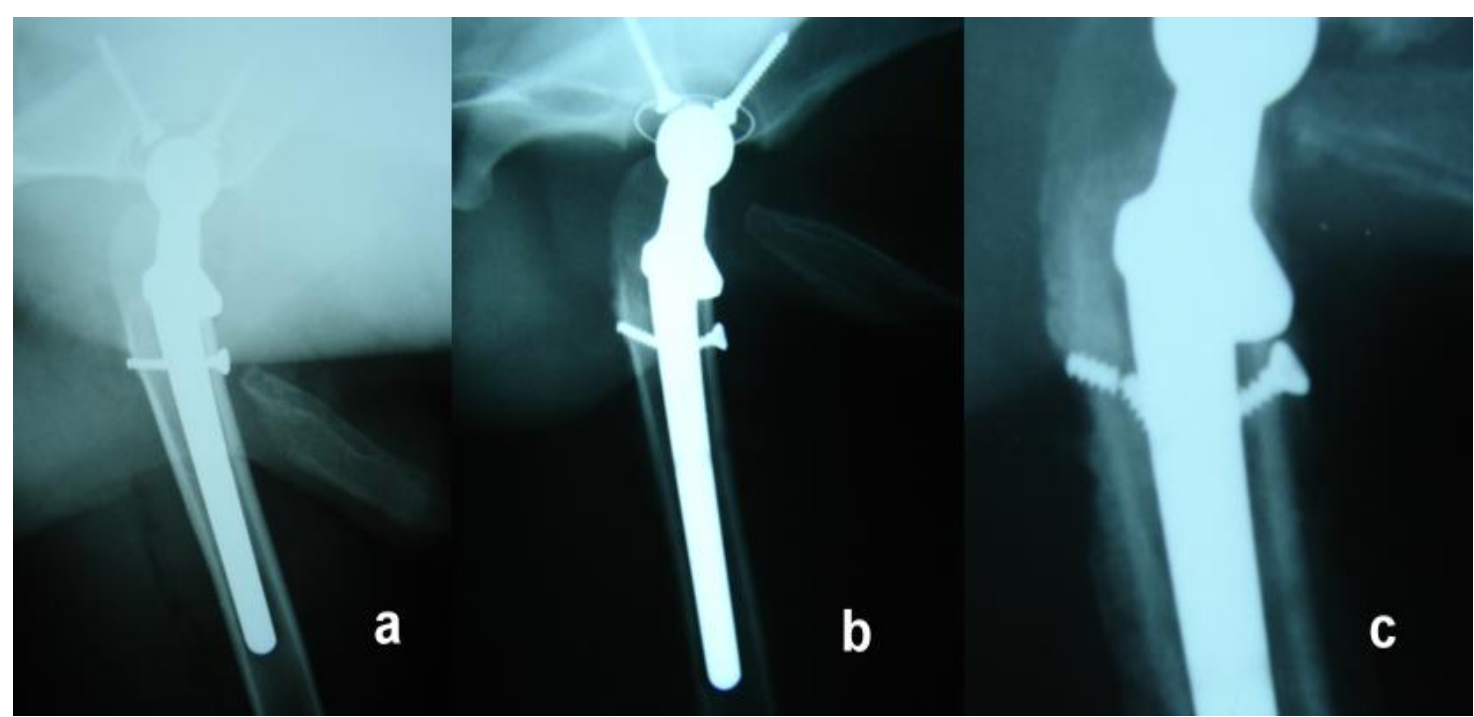

Figure 4. Radiographs of dog with cementless coated hip prosthesis (BCP). a) pelvis radiograph taken in medial-lateral position immediately after surgery, b) pelvis radiograph 15 days after surgery. Note the screw bending, c) pelvis radiograph 30 days after surgery. Screw fracture is revealed.

Table 1. Description of the degree of lameness characteristics criteria to evaluate dogs with cemented and cementless coxofemoral prosthesis.

\begin{tabular}{cl}
\hline Degree & Description \\
\hline 0 & Normal \\
1 & Normal walking, sporadic lameness at trot and gallop without limb elevation . \\
2 & Gait showing lameness in the operated limb at trot and gallop. Total weight limb bearing. \\
3 & Gait showing lameness in the operated limb at walking and trot. Partial weight bearing with \\
4 & Infrequent and intermittent support of the limb. No weight bearing. \\
5 & No limb use \\
\hline
\end{tabular}

The mean values of the thigh girth were evaluated using an ANOVA analysis of variance in split plot arrangement, where each type of prosthesis was a treatment. Each pelvic limb was the plot and the times of data collection the subplots. Means from each experimental group were compared using Duncan test $\mathrm{P}<0.05$. Qualitative data (lameness grade) was analyzed using non parametric Mann-Whithney test.

\section{RESULTS}

The characteristics of implant, length of surgery, radiographic position and results are summarized in Table 2. Transoperative cultures of implant area did not reveal any growth of bacteria. Body features of pelvis and femurs from animals lead to the use of three number 6 and three number 7 stems in each experimental group. The most frequently acetabular components implanted were 23 and $25 \mathrm{~mm}$, whereas six long neck (+6), three intermediate neck length $(+3)$ and three short (0) femoral heads were used. Surgical time was longer in cemented prosthesis and stem positioning within the femoral canal in ventrodorsal and medial-lateral radiographs were neutral and caudal, respectively.

The implantation of biphasic calcium phosphate coated acetabular component was relatively easier than cemented components and orifices distribution in the cementless components yield good results regarding acetabular cup orientation and fixation. Thicker components allowed better fitting and burying of the screw head. 
Modified cementless total...

Table 2. Characteristics from cemented and cementless coxofemoral prothesis used in dogs with total hip replacement

\begin{tabular}{|c|c|c|c|c|c|c|c|c|c|c|c|c|}
\hline \multirow[b]{2}{*}{ Animals } & \multicolumn{6}{|c|}{ Cemented prosthesis } & \multicolumn{6}{|c|}{ Cementless BCP prosthesis $(*)$} \\
\hline & 1 & 2 & 3 & 4 & 5 & 6 & 7 & 8 & 9 & 10 & 11 & 12 \\
\hline \multicolumn{13}{|l|}{$\begin{array}{l}\text { Acetabular } \\
\text { component }\end{array}$} \\
\hline $\begin{array}{l}\text { External diameter } \\
(\mathrm{mm})\end{array}$ & 23 & 25 & 23 & 23 & 25 & 21 & 25 & 25 & 25 & 23 & 29 & 27 \\
\hline $\begin{array}{l}\text { Internal diameter } \\
(\mathrm{mm})\end{array}$ & 14 & 17 & 17 & 14 & 17 & 14 & 14 & 14 & 17 & 14 & 17 & 17 \\
\hline Head & 0 & +3 & 0 & +6 & +6 & +-6 & +6 & +6 & 0 & +3 & +3 & +6 \\
\hline $\begin{array}{l}\mathrm{N}^{\circ} \text { orifices in the } \\
\text { acetabulum }\end{array}$ & 6 & 6 & 7 & 6 & 7 & 6 & 2 & 3 & 3 & 3 & 3 & 3 \\
\hline \multicolumn{13}{|l|}{ Screws } \\
\hline Diameter (mm) & - & - & - & - & - & - & 2.7 & 2.7 & 2.7 & 2.7 & 2,7 & 2.7 \\
\hline $\begin{array}{l}\text { Length crânio- } \\
\text { dorsal screw }\end{array}$ & - & - & - & - & - & - & 20 & 20 & 24 & 26 & 26 & 26 \\
\hline $\begin{array}{l}\text { Length crânio- } \\
\text { ventral screw }\end{array}$ & - & - & - & - & - & - & - & 12 & 10 & 14 & 12 & 12 \\
\hline $\begin{array}{l}\text { Length caudo- } \\
\text { dorsal screw }\end{array}$ & - & - & - & - & - & - & 18 & 10 & 18 & 16 & 20 & 26 \\
\hline Stem size & 6 & 7 & 7 & 6 & 7 & 6 & 6 & 6 & 7 & 6 & 7 & 7 \\
\hline Surgical time (min) & 232 & 170 & 225 & 189 & 228 & 217 & 182 & 192 & 248 & 175 & 185 & 197 \\
\hline $\begin{array}{l}\text { Culture - bacterial } \\
\text { growth }\end{array}$ & $\mathrm{Neg}$ & $\mathrm{Neg}$ & Neg & $\mathrm{Neg}$ & $\mathrm{Neg}$ & $\mathrm{Neg}$ & $\mathrm{Neg}$ & $\mathrm{Neg}$ & $\mathrm{Neg}$ & $\mathrm{Neg}$ & $\mathrm{Neg}$ & $\mathrm{Neg}$ \\
\hline \multicolumn{13}{|l|}{$\begin{array}{l}\text { Radiographic } \\
\text { positioning }\end{array}$} \\
\hline Antero-posterior & $\mathrm{Nt}$ & $\mathrm{Nt}$ & Var & $\mathrm{Nt}$ & $\mathrm{Nt}$ & Val & Var & $\mathrm{Nt}$ & $\mathrm{Nt}$ & $\mathrm{Nt}$ & $\mathrm{Nt}$ & $\mathrm{Nt}$ \\
\hline Medio-lateral & $\mathrm{Cd}$ & $\mathrm{Cd}$ & $\mathrm{Cd}$ & $\mathrm{Cd}$ & $\mathrm{Cd}$ & $\mathrm{Cd}$ & $\mathrm{Cd}$ & $\mathrm{Cd}$ & $\mathrm{Cd}$ & $\mathrm{Cd}$ & $\mathrm{Cd}$ & $\mathrm{Cd}$ \\
\hline
\end{tabular}

$(*)=$ coated with biphasic calcium phosphate; $\mathrm{Nt}=$ Stem neutral position; Var = varus stem; Val = valgus stem (radiographic cranio-caudal position); $\mathrm{Cd}=$ caudal position of the stem.

The preparation of the femoral canal was more laborious than preparation in dogs with cemented prosthesis, allowing mild press fitting implantation of the stem in the femur. The surgical technique for coated stem implantation was less aggressive to the femoral canal than cemented technique; orifices in the stem of coated prosthesis allowed bone growing and biologic fixation 120 days after surgery. Osteointegration and less aseptic loosening were the benefits when bioactive coating was used instead of cemented stems. Using interlocking screws through the stem was intended to provide early stability and biofixation. However, just one animal from coated cementless prosthesis group received the more proximal screw, because of the difficulty in localizing the second orifice when the stem was fitted within the femoral canal. Despite of the use of a perforation guide, small movements in the direction of the perforation axis led to misalignment of the guide and did not allow the localization of remaining orifices. As a consequence, an insufficient number of screws were inserted in the femur of this animal and extensive aggression to the soft tissues was observed at the time of vastus laterallis muscle elevation. On the $30^{\text {th }}$ postoperative day, radiographs showed a screw fracture (Figure 4), serious periosteal reaction and femoral remodelation. Consequently, an interlocking technique was declined, instead electing to fit the coated stem without screws by means of pressing within the femoral canal. 
Gait evaluations at the eighth postoperative week revealed that there were no signs of lameness in Group I animals (cemented) and just in one animal from Group II (cementless BCP); this animal remained limp until the $120^{\text {th }}$ day of evaluation. A qualitative comparison was made revealing that lameness was more prevalent in animals from cementless BCP hip prosthesis after 4 weeks of implantation than in animals in Group I (cemented). Although this observation did not have statistical significance, signs of pain were observed in the first 24 hours after surgery were more evident in animals from Group II; this fact was verified by the statistical test on the first postoperative day and proved by the severe lameness observed in the animals (Table 3.). Normalized body mass thigh girths from proximal, midpoint and epipatellar perimeters did not show any significant differences between groups during all intervals of evaluation; however, both groups showed statistical differences at all time intervals in the postoperative period.

Table 3. Degree of lameness of dogs with cemented/cementless (BCP) total hip prosthesis

\begin{tabular}{|c|c|c|c|c|c|c|c|c|c|c|c|c|c|c|}
\hline \multirow{4}{*}{ Days after surgery } & \multicolumn{13}{|c|}{ Treatments } & \\
\hline & \multicolumn{7}{|c|}{ Cemented } & \multicolumn{7}{|c|}{ Cementless BCP } \\
\hline & \multicolumn{7}{|c|}{ Animals } & \multicolumn{7}{|c|}{ Animals } \\
\hline & 1 & 2 & 3 & 4 & 5 & 6 & Mean & 7 & 8 & 9 & 10 & 11 & 12 & Mean \\
\hline $1 *$ & 3 & 4 & 4 & 5 & 4 & 5 & 4 & 5 & 5 & 5 & 5 & 5 & 5 & 5 \\
\hline 2 & 3 & 4 & 4 & 5 & 5 & 5 & 4 & 5 & 5 & 5 & 4 & 4 & 5 & 5 \\
\hline 3 & 3 & 4 & 3 & 5 & 5 & 5 & 4 & 4 & 5 & 5 & 4 & 4 & 5 & 5 \\
\hline 4 & 3 & 3 & 3 & 5 & 4 & 5 & 4 & 4 & 5 & 4 & 3 & 3 & 5 & 4 \\
\hline 5 & 3 & 3 & 3 & 5 & 4 & 5 & 4 & 4 & 5 & 4 & 3 & 3 & 5 & 4 \\
\hline 6 & 3 & 3 & 3 & 5 & 4 & 5 & 4 & 3 & 5 & 4 & 3 & 3 & 5 & 4 \\
\hline 7 & 3 & 3 & 3 & 5 & 4 & 5 & 4 & 3 & 4 & 4 & 3 & 3 & 5 & 4 \\
\hline 8 & 3 & 3 & 3 & 5 & 4 & 5 & 4 & 3 & 4 & 4 & 3 & 3 & 5 & 4 \\
\hline 9 & 3 & 3 & 3 & 5 & 4 & 5 & 4 & 3 & 4 & 4 & 3 & 3 & 5 & 4 \\
\hline 10 & 3 & 3 & 3 & 5 & 4 & 4 & 4 & 3 & 4 & 4 & 3 & 3 & 4 & 4 \\
\hline 11 & 3 & 2 & 3 & 5 & 4 & 4 & 4 & 3 & 4 & 3 & 3 & 3 & 4 & 3 \\
\hline 12 & 3 & 2 & 3 & 5 & 4 & 4 & 4 & 3 & 3 & 3 & 3 & 3 & 4 & 3 \\
\hline 13 & 3 & 2 & 3 & 4 & 3 & 4 & 3 & 3 & 3 & 3 & 3 & 3 & 4 & 3 \\
\hline 14 & 3 & 2 & 3 & 4 & 3 & 4 & 3 & 3 & 3 & 3 & 3 & 3 & 3 & 3 \\
\hline 15 & 3 & 2 & 3 & 4 & 3 & 3 & 3 & 3 & 3 & 3 & 3 & 3 & 3 & 3 \\
\hline \multicolumn{15}{|c|}{ Period Intervals -means } \\
\hline Day $16^{\text {th }}$ to $27^{\text {th }}$ & & & & & & & 3 & & & & & & & 3 \\
\hline Day $28^{\text {th }}$ to $29^{\text {th }}$ & & & & & & & 2 & & & & & & & 3 \\
\hline Day $30^{\text {th }}$ to $38^{\text {th }}$ & & & & & & & 2 & & & & & & & 2 \\
\hline Day $39^{\text {th }}$ to $45^{\text {th }}$ & & & & & & & 1 & & & & & & & 2 \\
\hline Day $46^{\text {th }}$ to $56^{\text {th }}$ & & & & & & & 1 & & & & & & & 1 \\
\hline Day $57^{\text {th }}$ to $59^{\text {th }}$ & & & & & & & 0 & & & & & & & 1 \\
\hline Day $60^{\text {th }}$ to $62^{\text {th }}$ & & & & & & & 0 & & & & & & & 0 \\
\hline Day $63^{\text {th }}$ to $120^{\text {th }}$ & & & & & & & 0 & & & & & & & 1 \\
\hline
\end{tabular}

* Estatistic significance $\mathrm{p}<0,021$.

In the group of dogs with the cemented prosthesis there were statistical differences in the girth over the midpoint and epipatellar perimeters after 30 days of surgery in the operated limb. There were no differences on the contra-lateral limb. Figure 4 represents the variation of the thigh midpoint perimeter in the operated and contra-lateral limb throughout the period of evaluation in both experimental groups. There was a reduction of both midpoint 
perimeters in each group, though animals with the cemetless prosthesis had greater reduction by fifteen days, postoperatively (Figure 5). Muscle mass recuperation was more evident in dogs with cemented prosthesis even at the $16^{\text {th }}$ week of postoperative period compared to the reference value showed before surgery on each group.

There were two femur fissure cases in the study. In the dog with cementless prosthesis, the fissure

Means from midpoint thigh girth operated limb

Vertical bars denote 0,95 interval confidence

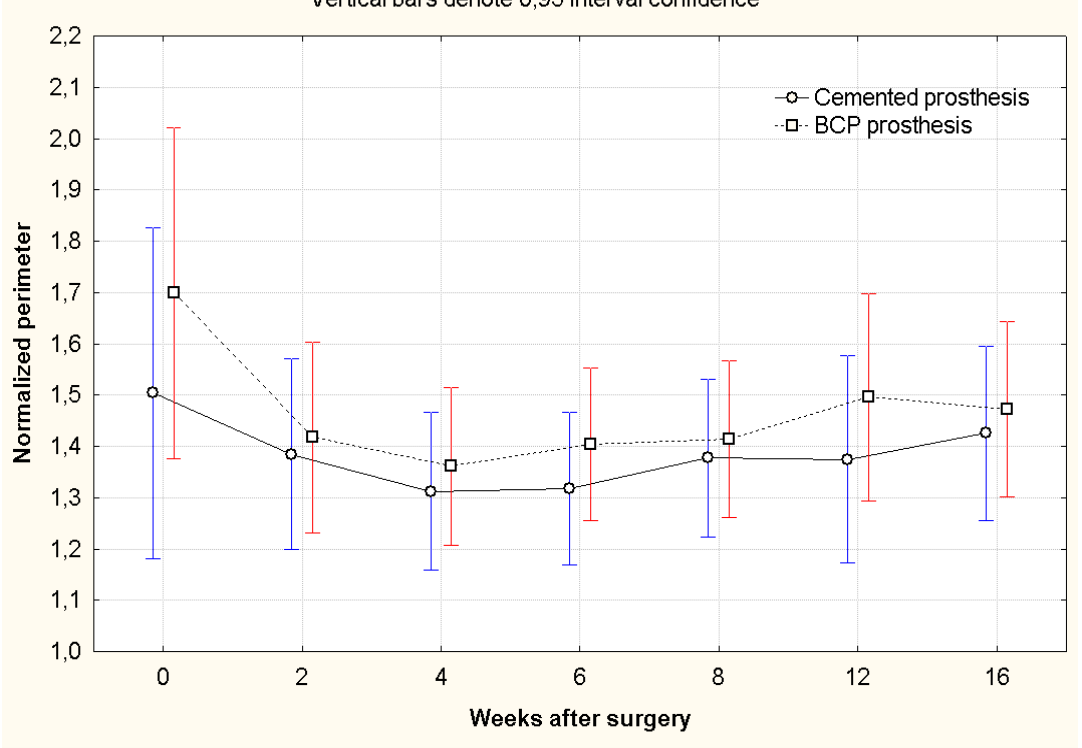

Means from midpoint thigh girth contra-lateral limb Vertical bars denote 0,95 confidence interval

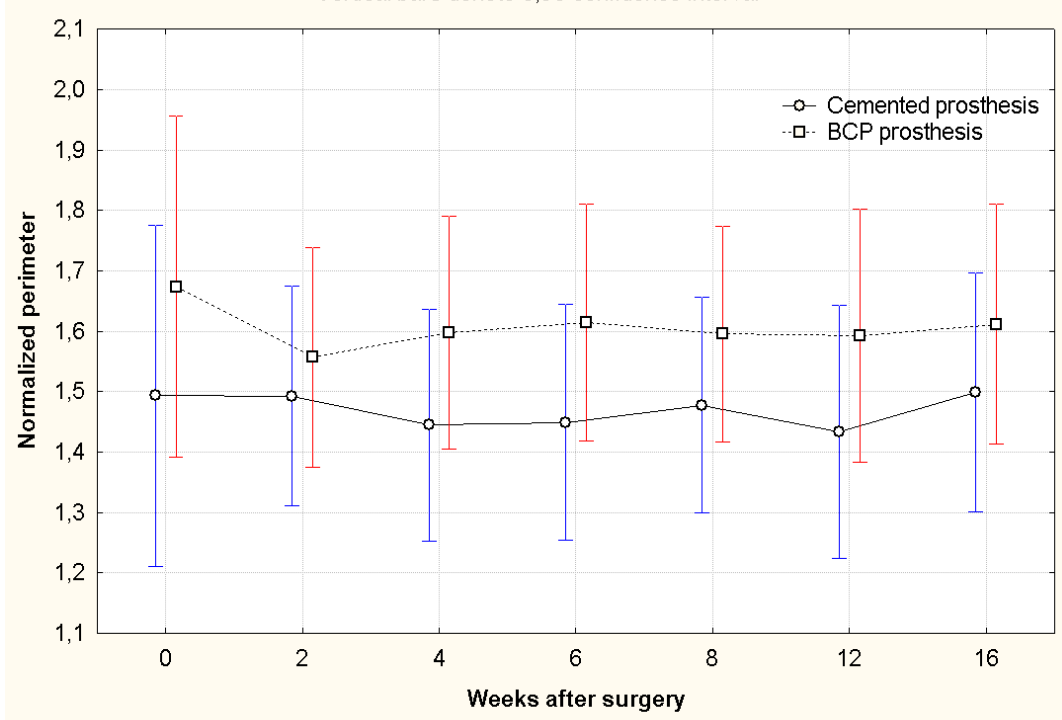

Figure 5. Means from midpoint girth in the operated and contra-lateral limb from dogs with cemented and cementless total hip replacement. 

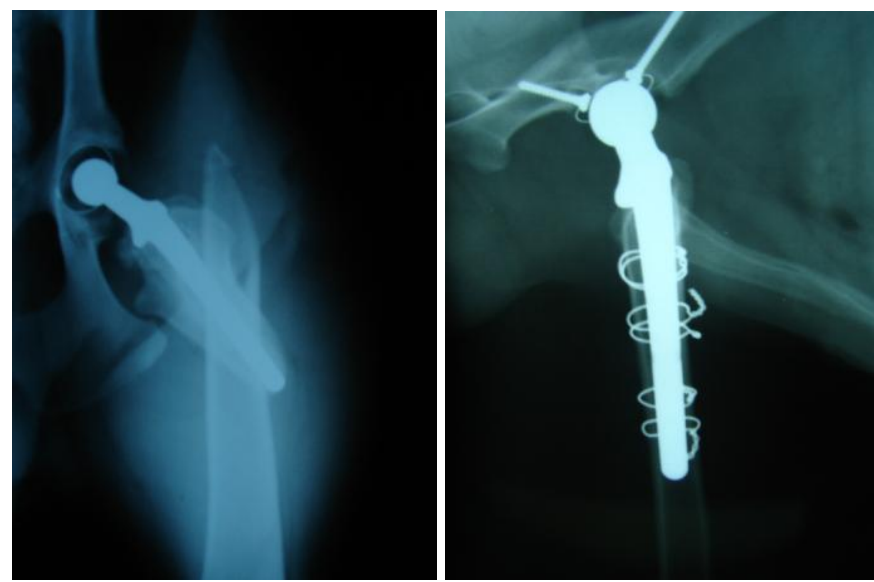

Figure 6. Radiographs from dogs with total hip replacement and femur fractures. Left: Ventro- dorsal radiograph from a dog with mid femoral proximal diaphisis fracture after cemented total hip replacement. Right: Latero-lateral radiograph from a dog with a cementless hip prosthesis after femoral fracture repair by means of cerclages.

Two dogs in each group showed temporary sciatic nerve neurapraxia that disappeared approximately two weeks after initial presentation and one had a femur fracture at the level of the stem tip during the anesthetic recuperation period (Figure 6). Two animals in this study were not included and replaced. In the first case, the cause was related to fissure expansion and, in the last, a cardiac alteration at necropsy was revealed, though without evidence of microscopic pulmonary emboli.

\section{DISCUSSION}

Total hip replacement is considered a salvage procedure and the last option to the surgeon when a dysplasic dog is treated (Tomlinson and McLaughlin, 1996). Previous studies (DeYoung et al., 1992; Skurla et al., 2000; Hummel et al., 2010) report good clinical results of dogs treated by means of implantation of hip prostheses (cemented and cementless). In human, complications for the two kinds of prosthesis have received good reports. However, advantages for cemented hip replacement include less postoperatory pain. Pulmonary embolism, cardio-respiratory collapse, cement systemic toxic effect, cardiac arrhythmias, longer surgery time and more bleeding are disadvantages reported for cemented prosthesis (Azegami et al., 2011). Our study was carried out in dogs and we found that surgery time is, in fact, shorter for cementless prosthesis and pain seems to be more severe for cementless than cemented prosthesis.
Our results agree with those found by Azegami et al. (2011). However, mortality after surgery due to pulmonary embolism, pneumonia, heart infarct or thrombosis is not a common complication reported in dogs. The use of porous-coated cementless prosthesis has been reported elsewhere (Chen et al., 1983; DeYoung et al., 1992; Marcellin-Little et al., 1999; Goyenvalle et al., 2006), nonetheless we did not find any report describing interlocking stems in association with bioactive coating in dogs. The Zurich total hip replacement model is a locked prosthesis intended for use in small animals, its rate of complications was reported around $11 \%$ (Hummel et al., 2010). Potential benefits from the interlocking system and coating may be the initial stability (which is required for osteoconduction) and the possibility for use in total hip replacement revision cases when osseous resorption, aseptic loosening and fractures are the main concerns (Murakami et al., 2003; Lauer et al., 2009). Reviewing the human complication rate for cementless prosthesis we found that when a bioactive stem coating is performed, aseptic loosening and stress shielding are diminished and the covering prolongs the rate of survival of the prosthesis in the patient (Emans et al, 2009; Pertegas et al., 2010; Mäkelä et al., 2011: Kim et al., 2012; Schwarzkopf et al., 2012). As a consequence, a better fixation, less stress shielding, and increased rate of survival than cementless or cemented prosthesis are the advantages reported for humans (Pertegas et al., 2010; Kim et al., 2012). By using the 
model here proposed we assume the same effect will occur in dogs after several years of implantation. This study aimed better osteointegration and less aseptic loosening for the cementless prosthesis by two strategies; first using bioactive coating instead of cement and second from an interlocking system intended for osteoconduction and osteointegration to occur, since initial stability is mandatory in this situation. Interfacial fibrous tissue formation between bone and cement (Hardy et al., 1999) is considered a disadvantage for biofixation and osteintegration. Press fitting and initial stability are required in order to provide biofixation in cementless hip prosthesis (Pernell et al., 1995), therefore a perfect fitting to the bone usually demands the use of larger stems (DeYoung et al., 1992; Montgomery et al., 1992; Pernell et al., 1995). According to these criteria, the use of interlocking screws through the stem was the initial idea to provide early stability and biofixation in this study. Nevertheless, despite the training in cadavers and the confection of the guide from these models, the difficulty to identify the second orifice in the stem of the prosthesis and the large tissue lesion, with prominent periosteal reaction examined in postoperative radiographies and screw fracture, took to the interruption in the use of the locking. The screw fracture occurred as a consequence of concentration of mechanical stress forces on the screw axis, which in turn was originated from the lack of other screws sharing the force. A single screw was insufficient to bear the force and stress; as a result the diameter of the screw became inappropriate to compensate the forces of the entire femur leading to the screw fracture.

Even with the problems observed and that the stem locked by biological fixation, the interlocking system used should not be dismissed. It might be useful in resolution and revision cases of total hip prosthesis femoral fracture (Liska, 2004), in such cases where it is not possible to position a plate with bicortical screw insertion because of the presence of the stem inside the canal impeding the insertion of the screws (Murphy et al., 1997; Liska, 2004). This study opened the possibility for using the locking prosthesis in cases which processes of osseous resorption, aseptic loosening and fractures are the main issues. For this purposes, it is necessary to perform modifications on the guide design and further studies developed.
Results from this study revealed the often use of acetabular components with small external diameter, (23 and 25) and 6 and 7 stems, which was related to the pelvis size and morphology of the mixed-breed animals used in the study. Concern exists when the polyethylene cup wears off to the point the metal head of the screws make contact with the stem head. This must be solved by using flat head screws or locking the acetabular component to the acetabulum with resorbable screws.

The stems were fitted properly to the morphology of the proximal femur. The employment of longer neck heads in $50 \%$ of the cases was partially due to the small trochanter level ostectomy, which in turn required longer necks for proper articular stability. Surgical time was longer in cemented prosthesis because of the time required for cement preparation and polymerization. Moreover, the learning curve may also have influenced the surgery time, once the animals with cemented prosthesis were the first to be operated, consequently more time was spent because of the lack of habituation with the new technique and time spent performing an accurate femoral canal preparation. However, Montgomery et al. (1992) reported shorter surgical time for cementless prosthesis than cemented implants according to our results and the human results (Azegami et al., 2011). Despite the relatively long surgery time of this study, which could have promoted prosthesis infection and contamination, negative culture tests were obtained showing that the employed asepsis and antisepsis were efficient. Literature mentions a considerable number of cases of bacterial growth in the samples collected during prosthesis implantation (Lee and Kapatkin, 2002).

Stem positioning within the femoral canal in ventro-dorsal and medio-lateral radiographs were neutral and caudal, respectively. Caudal stem positioning was probably obtained due to several reasons. First, there was lack of coupling between stem geometry and canine proximal femur morphology, so that the stem was forced into this position (Schulz et al., 2000; Warnock et al., 2003; Dearmin and Schulz, 2004). Second, using normal animals (without orthopedic alterations) with normal glutteal muscle mass might have led to difficult muscle retraction and 
elevation to complete a neutral femoral preparation and adequate stem orientation. In conclusion, when it comes to the use of the model of prosthesis here proposed, whether the utilization of an "Antler" lever as described by Howard \& William (1987), centralizers (Schulz et al., 1999) or undersizing the stem (Dearmin and Schulz, 2004) are the recommendations in order to obtain favorable results.

Gait differences between groups can be explained by the mattress effect of the layer of cement between bone and implant which absorbs the forces from the implant to the bone (Schulz, 2000; Katti, 2004). The bigger muscular hypotrophy in the animals with cementles prosthesis (BCP) suggests more painful recovery. The midpoint perimeter of the thigh is more reliable in describing variations of the muscle and limb usage, because it is less influenced by the adjacent structures, so it is considered the most efficient method of measuring muscle mass modifications. The proximal perimeter was influenced by the surgical wound healing, medial compensation and anteversion angle of the prosthesis, while the epipatellar perimeter by the position and flexion angle of the limb during measurement. The obtained results suggest that the evaluation period of 120 days for muscle hypotrophy was limited and insufficient, as the long term behaviour in both groups remains unknown. Recovery of the muscle mass with time progression is expected in the $\mathrm{BCP}$ prosthesis as already reported in non-cemented hip prosthesis in dogs (DeYoung et al., 1993). Despite the bigger muscle hypotrophy in animals with cementless BCP prosthesis, gait was not clinically affected. An increase of the thigh girth of the operated limb in dogs that underwent a total hip replacement has been reported in comparison to the contra-lateral limb (Massat and Vasseur 1994; Marcellin- Little, 1999). Results from our study differ from those previously reported and reveal that the animal without dysplasia actually does not compensate for the implantation of hip prosthesis; at least not in the first 16 weeks. These results were considered normal because it is expected that in clinical conditions the animal improve his performance until it regains the normal girth. The fact that animals with coxofemoral dysplasia reach the normal girth, demonstrates the efficacy of the procedure in improving performance, providing relief and comfort to the patient with this pathological condition.

Among complications of total hip replacement, fissures are more related to cementless hip implants and revealed in this study. These fissures were due to the proximal diameter stem incompatibility to the proximal diameter of the femur; canine latin prostheses even cemented have a larger proximal stem diameter than other commercial models leading to overpreparation of the femur canal by the surgeon, thus leading to microfissure formation. Other studies (Olmstead et al., 1983; Massat and Vasseur, 1994; Liska, 2004) report observation of the same fracture localizations and postoperative time of presentation. In this study, incidence of fractures and fissures were presented in either cemented or cementless systems with the same rate, which is in opposition to the report from Montgomery et al. (1992). To decrease the incidence of fractures, using stems with smaller diameters (undersizing) so that the procedure requires less broaching and reaming of the proximal femur is recommendable. In addition, it is necessary preoperatively to use a template and measure accurately the proximal diameter of the stem in relation to the proximal morphology of the femur in order to avoid x-ray magnification. Sciatic neurapraxia was another complication observed and related to the total hip replacement procedure as a consequence of muscular retraction (Olmstead et al., 1983).

Pulmonary emboli formation of air or fat when the stem is being implanted in the femur is a critical complication reported in humans, but rarely in dogs (Otto and Matis, 1994; Liska and Poteet, 2003). Even without histological proof of pulmonary emboli, in the presence of these signs, we consider emboli as the cause of death in one animal. More accurate methods like scintilographic and Doppler ultrasound studies would be more appropriate to establish the diagnosis in these cases (Liska and Poteet, 2003). Luxation is a common complication related to this technique (Olmstead et al., 1983; DeYoung et al., 1992; Olmstead, 1995; Marcellin-Little, 1999; Warnock et al., 2003), however we did not observe this complication. Both correct orientation of the components and its use in normal dogs could have led to the absence of this complication in this study. We encountered a $30 \%$ complication rate, which was considered 
high. Even though this result was similar to a few reports (Olmstead et al.; 1983; Warnock et al., 2003), it is possible that these results were affected by the experience of the surgeon (Olmstead, 1995).

\section{CONCLUSIONS}

The use of both the bioactive coated cementless model here proposed and cemented prosthesis was suitable to dogs, showing clinical satisfactory results. Animals that underwent cementless BCP hip prosthesis evidenced more pain, compared to animals with cemented hip prosthesis that required longer recovery time. New studies should be performed after improvement of the perforation guide to determine the viability of the interlocking hip prosthesis in revision cases of canine total hip replacement femoral fractures and bone loss. It is not necessary to lock the stem prosthesis to allow for bone growing; however it is really advantageous to perforate the stem in association with a bioactive coating. Implant osteointegration and a prevention of aseptic loosening are the advantages observed in this type of prosthesis when compared to cemented systems.

\section{REFERENCES}

AZEGAMI, S.; GURUSAMY, K.S; PARKER, M.J. Cemented versus uncemented hemiarthroplasty for hip fractures: a systematic review of randomized controlled trials. Hip. Int., v.21, p.509-517, 2011.

CHEN, P.Q.; TURNER, T.M.; RONNINGEN, H. et al. A canine cementless total hip prostheses model. Clin. Orthop. Relat. R., v.176, p.24-33, 1983.

DAY, M.J.; BUTTERWORTH, S.J.; PALMER, M.R. Characterization of wear debris associated with aseptic loosening of a canine hip prosthesis. J. Comp. Pathol., v.119, p.89-93, 1998.

DEARMIN, M.G.; SCHULZ, K.S. The effect of stem length on femoral component positioning in canine total hip arthroplasty. Vet. Surg., v.33, p.272-278, 2004.

DeYOUNG, D.J.; DeYOUNG, B.A.; ABERMAN, H.A. et al. Implantation of an uncemented total hip prosthesis technique and initial results of 100 arthroplasties. Vet. Surg., v.21, p.168-177, 1992.
DeYOUNG, D.J.; SCHILLER, R.A.; DeYOUNG, B.A. Radiographic assessment of a canine uncemented porous coated anatomic total hip prosthesis. Vet. Surg., v.22, p.473-481, 1993.

EMANS, P.J.; BROEKE, R.H.; VAN MULKEN J.M. et al. Results of total hip arthroplasties in the young patient further evidence for a barrier against articular wear debris by hydroxyapatite coatings. Hip Int., v.19, p.343-351, 2009.

FENOLLOSA, J.; SEMINARIO, P.; MONTIJANO, C. Ceramic hip prostheses in young patients: a retrospective study in 74 patients. Clin. Orthop. Relat. $R .$, v.379, p.55-67, 2000.

GOYENVALLE, E.; AGUADO, E.; NGUYEN, J.M. et al. Osteointegration of femoral ítem prostheses with a bilayered calcium phosphate coating. Biomaterials, v.27, p.1119-1128, 2006.

HANSON, S.P.; PECK, J.N.; BERRY, C.R. et al. Radiographic evaluation of the zurich cementless total hip acetabular component. Vet. Surg., v.35, p.550-558, 2006.

HARDY, D.C.; FRAYSSINET, P.; KRALLIS, P. et al. Histopathology of a well functioning hydroxyapatite-coated femoral prosthesis after 52 months. Acta orthop. Belg., v.1, p.72-82, 1999.

HOWARD, A.P.; WILLIAM, L.B. A modified technique for canine total hip replacement. J. Am. Anim. Hosp. Assoc., v.23, p.13-18, 1987.

HUMMEL, D.W.; LANZ, O.I.; WERE, S.R. Complications of cementless total hip replacement: A retrospective study of 163 cases. Vet. Comp. Orthopaed., v.23, p.424-432, 2010.

JASTY, M.; BRAGDON, C.R.; ZALENSKI, E.; O'CONNOR, D. et al. Enhanced stability of uncemented canine femoral components by boné ingrowth into the porous coatings. J. Arthroplasty., v.12, p.106-113, 1997.

KATTI, K.S. Biomaterials in total joint replacement. Colloid. Surface. B., v.39, p.133-142, 2004.

KIM, Y.H.; KIM, J.S.; JOO, J.H.; PARK, J.W. Is hydroxyapatite coating necessary to improve survivorship of porous-coated titanium femoral stem? J. Arthroplasty., v.2, p.559-563, 2012.

LAUER, S.K.; NIEVES, M.A.; JEFFREY PECK, J. et al. Descriptive histomorphometric ingrowth analysis of the zurich cementless canine total hip acetabular component, Vet. Surg., v.38, p.59-69, 2009.

LEE, K.C.; KAPAKTIN, A.S. Positive intraoperative cultures and canine total hip replacement: risk factors, periprosthetic infection, and surgical success, J. Am. Anim. Hosp. Assoc., v.38, p.271-278, 2002. 
LISKA, W.D. Femur fractures associated with canine total hip replacement. Vet. Surg., v.33, p.164-172, 2004.

LISKA, W.D.; POTEET, B.A. Pulmonary embolism associated with canine total hip replacement. Vet. Surg., v.32, p.178-186, 2003.

MÄKELÄ, K.T.; ESKELINEN, A.; PULKKINEN, P. et al. Results of 3,668 primary total hip replacements for primary osteoarthritis in patients under the age of 55 years, Acta Orthop., v.82, p.521-529, 2011.

MARCELLIN-LITTLE， D.J.; DeYOUNG， B.A; DOYENS, D.H. et al. Canine uncemented porouscoated anatomic total hip arthroplasty: results of a long-term

prospective evaluation of 50 consecutive cases. Vet. Surg., v.28, p.10-20, 1999.

MASSAT, B.J. Artroplastia cementada total de la cadera canina. Waltham Focus, v.5, p.21-31, 1995.

MASSAT, B.J.; VASSEUR, P.B. Clinical and radiographic results of total hip artroplasty in dogs: 96 cases (1986-1992). J. Am. Vet. Med. Assoc., v.205, p.448-454, 1994.

MONTGOMERY, R.D.; MILTON, J.L.; PERNELL, R. et al. Total hip arthroplasty for treatment of canine hip dysplasia. Vet. Clin. N. Am-small., v.22, p.703719, 1992.

MURAKAMI, N.; SAITO, N.; TAKAHASHI, J. et al. Repair of a proximal femoral bone defect in dogs using a porous surfaced prosthesis in combination with recombinant BMP-2 and a synthetic polymer carrier. Biomaterials, v.24, p.2153-2159, 2003.

MURPHY, S.T.; PARKER, R.B.; WOODARD, J.C. Osteosarcoma following total hip arthroplasty in a dog. J. Small Anim. Pract., v.38, p.263-267, 1997.

OLMSTEAD, M.L. Canine cemented total hip replacements: state of the art. J. Small Anim. Pract., v.36, p.395-399, 1995 .

OLMSTEAD, M.L.; HOHN, R.B.; TURNER, T.M. A five-year study of 221 total hip replacements in the dog. J. Am. Vet. Med. Assoc., v.183, p.191-194, 1983.

OTTO, K.; MATIS, U. Changes in cardiopulmonary variables and platelet count during anesthesia for total hip replacement in dogs. Vet. Surg., v.23, p.266-273, 1994.
PARK, S.H; LLINÁS, A.; GOEL, V.K. et al. Hard tissue replacements; In: BRONZINO, J.D. The Biomedical Engineering Handbook, Connecticut: CRC Press, 1995. p.672-691

PERNELL, R.T.; MILTON, J.L.; GROSS, R.S. et al. The effects of implant orientation, canal fill, and implant on femoral strain patterns and implant stability during catastrophic testing of a canine cementless femoral prosthesis. Vet. Surg., v.24, p.337-346, 1995.

PERTEGAS, M.V.; VERGARA, V.; CRUSISERELOLRS, X.; SANCHO, R.N. Fully hydroxyapatite-coated hip replacement: ten-year results. Hip. Int., v.20, p.s79-s85, 2010.

SARGEANT, A.; GOSWAMI, T. Hip implants: paper V. physiological effects. Mat. Design., v.27, p.287307, 2006.

SCHULZ, K.S.; STOVER, S.M.; KASS, P.H. et al. Effect of surgical technique and use of a rigid centralizing device on stem positioning and geometric reconstruction in the sagittal plane during total hip replacement in canine cadavers. Am. J. Vet. Res., v.60, p.1126-1135, 1999.

SCHULZ, K.S. Application of arthroplasty principles to canine cemented total hip replacement. Vet. Surg., v.29, p.578-593, 2000.

SCHULZ, K.S.; NIELSEN, C.; STOVER, S.M. et al. Comparison of the fit and geometry of reconstruction of femoral components of four cemented canine total hip replacement implants. Am. J. Vet. Res., v.61, p.1113-1120, 2000.

SCHWARZKOPF, R.; OLIVIERI, P., JAFFE, W.L. Simultaneous bilateral total hip arthroplasty with hydroxyapatite-coated Implants: a 20-year follow-up. J. Arthroplasty, v.27, p.1364-1369, 2012.

SILVA, S.N.; PEREIRA, M.M.; BRANCO, J.R., et al. Desenvolvimento de recobrimentos bioativos sobre ligas metálicas de aço inox (AISI 316L) e titânio. Rev. Unileste, v.1, p.1-16, 2005.

SKURLA, C.T.; EGGER, E.G.; SCHWARZ, P.D. et al Owner assessment of the outcome of total hip arthroplasty in dogs. J. Am. Vet. Med. Assoc., v.217, p.1010-1012, 2000

TOMLINSON, J.; McLAUGHLIN, R. Total hip replacement: the best treatment for displastic dogs with osteoarthrosis, Vet. Med., v.91, p.118-124, 1996.

WARNOCK, J.J.; DYCE, J.; POOYA, H. et al. Retrospective analysis of canine miniature total hip prostheses, Vet. Surg., v.32, p.285-291, 2003. 